AndryeyevaViktoriya, $\mathrm{PhD}$ in Economics, Associate Professor, Kyiv National University of Trade and Economics, Kyiv, Ukraine ORCID: 0000-0002-9529-0543

Researcher ID: M-8807-2016

Laptieva Viktoriia, $\mathrm{PhD}$ in Economics, Associate Professor, Kyiv National University of Trade and Economics, Kyiv, Ukraine ORCID: 0000-0001-8218-7953

Researcher ID: M-8576-2016

Afanasyev Kostyantyn, $\mathrm{PhD}$ in Economics, CEO of Consulting Company Globus Kyiv, Ukraine ORCID 0000-0002-4613-3525

\title{
CORPORATE INNOVATION: FROM AN IDEA TO COMMERCIALIZATION
}

Corporate innovation is an effective tool for meeting the challenge of organic economic growth for companies in a highly competitive environment. The article defines the basic prerequisites for innovation in enterprises and systematizes the risks associated with undertaking an innovation activity, as well as the implementation of innovation. The essence of the main programs of development of corporate innovations is considered: the program of internal entrepreneurship; corporate business incubator; partnership with technology centers (universities), taking into account the experience of leading foreign and domestic companies, identified the advantages and disadvantages of their application. The efficiency of using open innovation in various forms as the most adaptable to modern conditions of functioning of domestic enterprises and their business models is substantiated.

Keywords: corporate investment, business model, internal entrepreneurship, business incubator, technology centers (universities). 
Андрсєва Вікторія, Лаптева Вікторія, Афанасьєв Костянтин. Корпоративні інновації: від ідеї до комерціалізації

Корпоративні інновації - це ефективний інструмент для вирімення задачщодо органічного економічного зростання компаній у висококонкурентному середовищі.У статті визначено основні передумови інновацій на підприсмствах та систематизовано ризики, пов'язані із здійсненням інноваційної діяльності, а також впровадженням інновацій. Розглянуто сутність основних програм розвитку корпоративних інновацій: програма внутрішнього підприємництва; корпоративний бізнес-інкубатор; партнерство з технологічними центрами (університетами) з урахуванням досвіду провідних зарубіжних та вітчизняних компаній, визначено переваги та недоліки їх застосування. Обтрунтовано ефективність використання відкритих інноваиій у різних формах як найбільш адаптивних до сучасних умов функиіонування вітчизняних підприємств та їх бізнес-моделей.

Ключові слова: корпоративніінвестииії, бізнес-модель, внутрішнє підприсмництво, бізнес-інкубатор, технологічні центри (університети).

Relevance of research topic. Ensuring the innovative development of corporations is the basis for their dynamic growth and entry into international markets in a globally competitive environment, as evidenced by global economic trends. Continuous competition, both through the emergence of new products and new businesses and industries, makes it impossible or extremely difficult to find, create and implement innovations within traditional existing business processes, so corporate innovation is no longer a trend, but a need that allows businesses to grow fast and overcome the crisis with confidence. Innovations allow you to upgrade your company values, optimize and properly utilize all types of resources, streamline business processes and effectively implement change, quickly create new products that will ensure long-term business success, and ultimately increase the company's profitability and market value.

Formulation of the problem. According to the Global Competitiveness Index, published by the World Economic Forum in 2017-2018, Ukraine ranked 81st out of 137 countries, improving its position compared to 2016-2017 by four points (for comparison, Georgia ranked 67th). Poland - 39, Russia - 38), with the innovative component of the Index reduced by as much as nine points (61st out of 137 countries) [7]. Accordingly, it is necessary to increase the competitiveness of domestic enterprises, that is, the search for such business models that will respond promptly to changes in the environment and offer high-tech innovative solutions to bridge the striking gap with leading competitive states.

Analysis of recent research and publications. The issue of improving the effectiveness of corporate innovation management has received considerable attention from researchers. It should be noted that J. Schumpeter, who in his book «The Theory 
of Economic Development» [6] was the first to apply the concept of innovation and highlight their paradoxical nature. He stated that the innovation «would strike not only the profit and production activity of existing companies, but its very existence» and called the innovation «a creative disruption» [6]. Another foreign scientist who has researched innovative strategies of the innovator is I. Ansoff in the book «Strategic Management» [1]. A. Osterwalder, Y. Pigneur's book «Business Model Generation» is devoted to the question of necessity of change of traditional business models to modern innovative ones, their development and implementation [4]. In addition, important contributions to the development of the nature of innovation and features of management have made: S. Blank, B. Dorf, P. Drucker, E. Mansfield, K. Opplander, E. Ries, R. Waterman, G. Chesborough. Among the domestic researchers who have studied the issues of corporate investment should be noted: L.S. Blyakhman, V.P. Loginova, A.G. Kruglikova, V.M.Rudzitsky, R.A. Fathutdinova et al.

At the same time, the constant and rapid changes of highly competitive markets require constant research and modernization of the types, forms, methods and tools of corporate innovation implementation.

Presenting main material. Given the relevance of the research topic, the main prerequisites for innovation in enterprises are:

- the need to maintain and grow market positions in the conditions of fierce competition and technological breakthrough, which cannot be ensured in the framework of existing business models that do not involve innovative solutions and will in the future lead to a decrease in operational efficiency;

- the need to meet the real and hidden needs of consumers, manage changes to these needs and its programming. That is, an enterprise needs to give up the production of an old product in time and quickly bring to market a new successful product or solution;

- understanding the need to innovate and the availability of opportunities, appropriate mechanisms and tools for implementation;

- the need to reduce the cost of products and accelerate business processes through the rapid introduction of new technologies;

- availability of creative potential of employees of the enterprise, their desire to be involved in the process of solving problems of the enterprise;

- shortening the life cycle of an enterprise: so if in 1965 the average length of life cycle of enterprises on the S\&P list was 33 years, in $1990-20$ years, by 2026 it is projected to decrease to 14 years [5].

The path to effective innovation should take into account the risks that can be divided into two groups: related to the enterprise's need for innovation and implementation of innovation.

The main risks of the enterprise in terms of the need to carry out innovative activities should include: 
- underestimation of the role of innovation in the development of the enterprise and strengthening of its competitive advantages;

- fear of the need to innovate and change the existing traditional model;

- low culture of entrepreneurship (lack of desire and knowledge for promotion of new ideas by employees; lack of interest and lack of support for innovations by the management of the enterprise; ineffective communication between different levels of management and departments;

- lack of knowledge transfer; inefficient system of motivation;

- lack of material, intellectual, human and financial resources to innovate.

The main risks associated with the implementation of enterprise innovation are:

- the destruction of the old, inefficient existing business model in the absence or insufficient development of a new one, which can lead to a decrease in the volume of operating activities of the enterprise and loss of positions in the market;

- lack of instant result from innovation or the result may be different from what was planned;

- implementation of an innovative solution outside the enterprise, both by its employees (unless appropriate conditions for implementation were created) and by employees created by other enterprises;

- ineffective system of practical evaluation of innovation implementation results.

Among the large number of corporate innovation development programs, it is advisable to distinguish the following: internal entrepreneurship program; corporate business incubator; partnership with technology centers (universities).

1. An internal entrepreneurship program is the concept of motivating creative ideas and skills within an existing organization and investing in their implementation.

For instance, Adobe developed Kickbox for its own internal use and created both a process for individualsand a system for deploying that process across an organization at scale. It's designed to increase innovator effectiveness, accelerate innovation velocity, and measurably improve innovation outcomes. It can also optimize innovation investments by reducing costs compared to traditional approaches. The top of the box features a clever fire alarm image with the words «Pull in Case of Idea» written on it. When you break open the seal, you will find instruction cards, a pen, two «postit» notepads, two notebooks, a Starbucks gift card, a bar of chocolate and (mostly importantly) a $\$ 1,000$ prepaid credit card. The card can be used on anything the employee would like or need without ever having to justify it or fill out an expense report [2]. The Adobe methodology enables employees to experiment, and managers understand in advance about the existence of a project that delivers results.

The main advantages of the internal entrepreneurship program are: involvement of employees of the enterprise, who are closest to the business and understand the processes that are going on, and their focus on the achievement of management goals; forming a sense of ownership; the effectiveness of identifying internal problems and 
new creative ideas to solve them; joint development of innovations, absence of necessity of investment of big funds for realization of only one or several projects.Risks of the internal entrepreneurship program are: unwillingness of the enterprise to trust employees, lack of resources for realization, inefficient staffing of the team of innovators, fear of possible failure.

2. Corporate business incubator consists of small clusters and creative associations of employees, created at the enterprise for development and implementation of innovations. It is based on giving access to the resources of the corporation (premises, equipment, technologies, information, analytical, resources, financing, etc.), that is, things that most likely would not be available outside the corporation).

While in 2010 only $2 \%$ of the world's largest companies used corporate incubators and accelerators to develop young projects, in 2016, 44\% did so [3].

For example, Allianz Digital Labs in Munich places startups in their offices; GE Garages gives you the opportunity to collaborate with startups in many ways; Microsoft Ukraine has set up an IoT lab where eight startups are currently incubating projects with Internet of Things projects.

Types of corporate business incubator are open innovation programs, the essence of which is to solve the problems of the company on the basis of gathering ideas on the network, most often, for reward and hackathons- forums of developers of different directions, which together solve the task and attract the necessary personnel. So, in 2010, one of the TechCrunch hackers sold Skype for $\$ 85$ million.

Accelerators are used by companies such as Citrix, Intel, MasterCard, Orange, etc.; Kyivstar uses Radar Tech telecom-accelerator: five startups are currently incubated; Mironovsky Bakery also launched a joint venture with Radar Tech, an innovative accelerator for agrarian startups. It selects twenty five applicants, of which the top ten will be accelerated and the winners will work with the company.

The main advantages of a corporate business incubator are: enterprises are changing in accordance with current world trends and future technologies, without distracting themselves from operating activities, which now make the major part of profits; reducing the time for finding and launching a new product; capitalization of innovation; identify and attract the most talented staff. The main risks are: research results are often seen in isolation from other innovative steps of the enterprise; most startups will not be implemented in the short-term or at all. For example, as part of IBM's 2003 Emerging Business Opportunities program, 25 startups were created over a five-year period, of which only three failed to make a profit. The other 22 in 2008 brought in $\$ 15$ billion in revenue [3].

3. Partnerships with Technology Centers (Universities)involve collaboration between corporations and academia, enabling companies to access new technologies and projects in the early stages of development, as well as connect with reputable educational institutions. 
Among the companies that actively cooperate with higher educational establishments of Ukraine in the economic direction, the following should be mentioned: Watsons, Ernst\&Young, Procter\&Gamble, Philip Morris, L'Oreal, etc.; technical areas: Microsoft, IBM, Samsung Electronics, etc.

In addition to universities, new resources for the provision of technical education are being disseminated, such as General Assembly, an innovator in online education that provides a large number of advanced training in programming, marketing, design, business and career development; Galvanize is the learning community for technology. Their partners, who offer jobs for graduates of educational programs, are such well-known companies as Google, Microsoft, Visa, L'Oreal, Conde Nast and others.

The main benefits of partnering with technology centers (universities) are: increasing the innovationsin the companies' activities and transforming their operating activities into high-tech ones, which increases their competitiveness in the market; attracting highly qualified personnel; expansion of business functions; participation in the creation of joint venture funds; participation in the educational process of higher education institutions; raising their own attractiveness, recognition, loyalty of the state and acceptance by the society. The main risk may be related to the allocation of intellectual property rights.

According to the research, in countries with developed market economy in corporations there is a rapid transition from closed to open innovation, characterized by the following advantages: a large number of innovations and the ability to synthesize their own and external ideas; cooperation of the best specialists of the enterprise with innovators beyond its borders; the possibility of involving consumers in the development of innovations; the variety of types of innovation; significant volume and branching of the resource base; reducing the time to search and develop innovation; the ability to involve the enterprise in the development of innovation at any stage of the process; differentiation of new products, and accordingly expansion of the circle of consumers and receipt of additional income; profit on the basis of cooperation and the sale of intellectual property. The disadvantages of this transition are: the complex nature of the organization of innovation; lack of complete control over the processes by the corporation; presence of external risks in combination with internal risks; problems with defining ownership of the invention and the mechanism of profit sharing.

Thus, given the prospects and risks of corporate innovation development, the benefits and disadvantages of implementing corporate programs, the use of open innovation can be more effective, as their business models can best be built according to strategic goals, available resources and internal features of domestic enterprises.

Conclusion. In today's environment, innovation has evolved from a corporate business development tool to a prerequisite for its survival. An effective corporate innovation management system ensures dynamic growth of the company, creation of 
significant additional value, growth of income and profit. To do this, it is necessary to constantly develop and improve innovative processes in the enterprise, which will provide competitive advantages. The most effective is the open innovation model, which combines both the internal resources of the corporation itself and the external ones for the development, implementation and commercialization of new ideas the application of which is offered for domestic enterprises.

\section{REFERENCES}

1. Ansoff, H. Igor (1979). Strategic Management. Retrieved from https://books.google.com.ua/books?id=bV9_Svdum70C\&pg=PA1\&hl=ru\&source=gb $\mathrm{s} \_$toc_r\&cad $=4 \# \mathrm{v}=$ onepage $\& \mathrm{q} \& \mathrm{f}=$ false

2. Harvard Business Review (2019). Retrieved from https://kickbox.org

3. Internal entrepreneurship - how employees changethe corporation inside. (2018). (Vnutrishnje pidprijemnitstvo - jak spivrobitniki zminjujut korporatsiji vseredini). Retrieved from https://biz.nv.ua/ukr/tech/vnutrishnje-pidprijemnitstvo-jakspivrobitniki-zminjujut-korporatsiji-zseredini-2499358.html

4. Osterwalder, A., Pigneur, Y. (2010). Business Model Generation. Retrieved from http://radio.shabanali.com/business-model-generation-osterwalder.pdf

5. S\&P Global (2019). Retrieved from https://www.standardandpoors.com

6. Schumpeter, Joseph A. (1949). The Theory of Economic Development: An Inquiry into Profits, Capital, Credit, Interest, and the Business Cycle. Retrieved from https://archive.org/details/in.ernet.dli.2015.187354/page/n265

7. The Global Competitiveness Report 2017-2018 (2018). Retrieved from https://www.weforum.org/reports/the-global-competitiveness-report-2017-2018 